\title{
A new area of application and research in bio-processes: Biotechnologies in civil construction
}

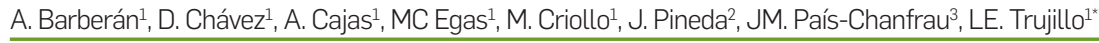

DOI. 10.21931/RB/2020.05.01.11

Abstract: Construction Biotechnology is a new scientific and engineering discipline that has been developing exponentially during the last decade. The main directions of this discipline are 1- the selection of adequate microorganisms, 2- development of microprocessed construction bioprocesses as well as 3- the development of new biotechnologies to produce construction biomaterials. Products resulting in construction biotechnologies are low-cost, sustainable, and environmentally friendly microbial biocements for the improvement of the construction terrain. The bioagents used in construction biotechnologies are pure or enrichment cultures of native microorganisms or microorganisms isolated and activated from the soil. Biotechnologically produced construction materials and microbial mediated construction technologies have many advantages compared to conventional construction materials and processes. The current technological landscape offers an objective vision and perspective of how microbes are used in the construction industry as additives for cement and concrete so that these new technologies be used in different provinces of Ecuador. In that sense, the current situation of cement and concrete production in Ecuador is briefly described to have an overview of the applicability of the new methods based on biogenic materials and the environmental advantages of the creation of construction biomaterials over conventional production.

KeyWords: Cement, concrete, biomaterials, biogenic, biotechnological, microorganisms.

\section{Introduction}

Construction Biotechnology is a new scientific discipline, named in such a way due to its analogy with medical, environmental, agricultural and food biotechnology. This modern science successfully combines the application of scientific knowledge about engineering methods for the production of construction biomaterials as well as the use of bioprocesses in the construction industry ${ }^{1-3}$.

The use of construction biomaterials is one of these novels, friendly and sustainable alternatives since the raw material used mostly is renewable biological resources, e.g. agricultural biomass residues and recently also waste microorganisms resulted from other industries have gained popularity for its production ${ }^{3}$.

The industry-related with the conventional production of construction materials consumes a large amount of energy being harmful to the environment. The power consumed represents between 20 and $40 \%$ of the total production cost; however, there are novel alternatives that reduce up to $10 \%$ of the energy used in conventional manufacturing ${ }^{1,4}$.

Different biotechnological products and biotechnologies applied to civil engineering are being developed in that direction (figure 1). The reduction of the environmental impact of the conventional production of construction materials together with a decrease in production costs, use of waste in secondary processes, increased quality and useful life of the materials obtained. These issues, among others, constitute the main advantages of this technology.

The use of biologically based products has increased at a steady pace in the last decade. It is estimated that by 2020 the global market based on bioproducts reaches $\$ 250$ billion and that by 2030 a third of the materials that will be produced will come from biological resources ${ }^{5}$. This study raises the possibility of implementing bio-cements and bio-concrete in Ecuador based on economic reviews and its possible application in several areas where there is a higher demand for construction. Provinces of Pichincha and Guayas, due to their characteristics of great cement producers, could be the main areas to study these environmentally friendly materials.

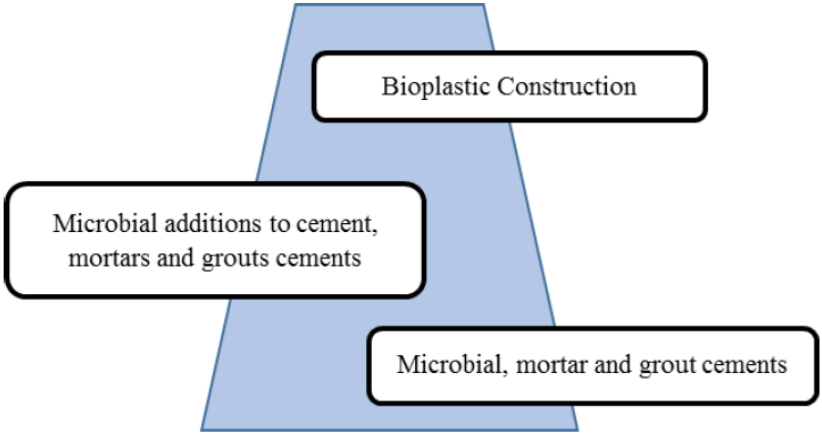

Figure 1. Overview of Biotechnology strategies used for construction materials.

\section{Current situation of convencional cement and concrete production in ecuador}

In 2010, the net profitability of the conventional cement production market was $31.56 \%$, billing 600 million dollars, adding the real estate boom and the works carried out by the government, which undoubtedly boosted the production and consumption of this item as seen in figure 2.

Figure 3 shows that the provinces of Pichincha and Guayas had the highest cement consumption at that time due to the sizeable real estate growth. It should be taken into account, and as a curious fact, the number of competitors in this branch is quite low in the country since there are only four companies immersed in this area, being two of them private multinationals Holcim and Lafarge, and the public companies, Chimborazo and Guapán.

As another curious fact, the cost of 1 cement sack was about \$8-9.00 US, one of the lowest prices in the market compared to other countries in the region like Bolivia, Colombia, or Venezuela. 


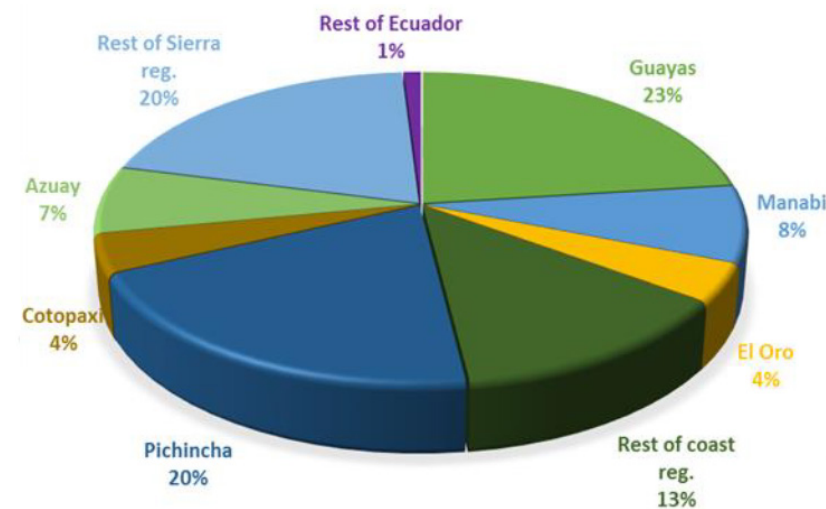

Figure 2. Monthly marketing of gray cement (in tons) $)^{6}$.
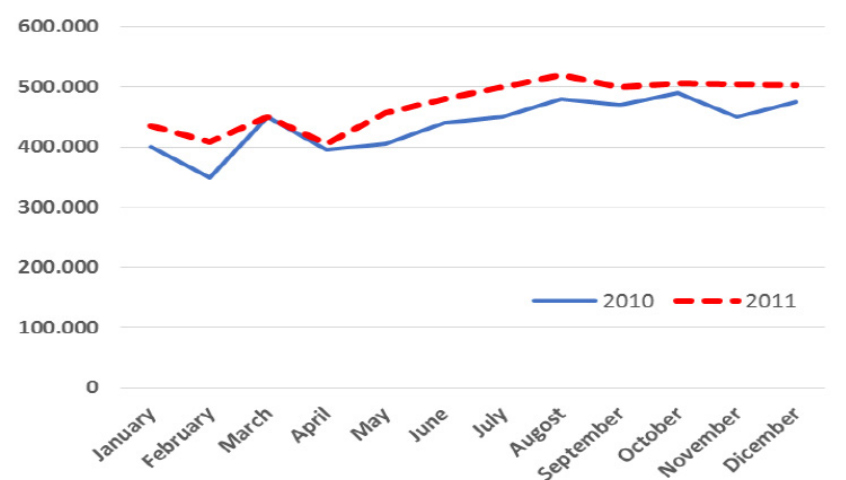

Figure 3. The concentration of Sales by Province ${ }^{6}$. 10,0

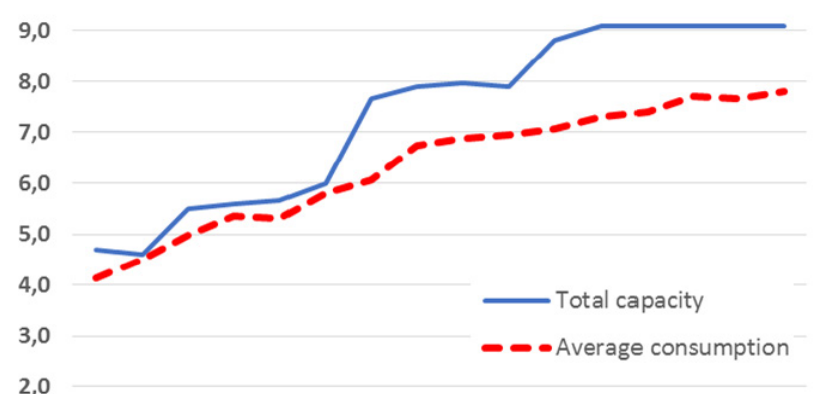

1,0

0,0

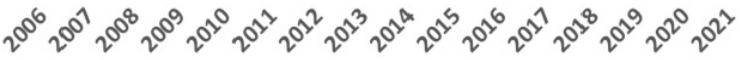

Figure 4. Cement growth projections (in millions of tons per year) $)^{6}$.

According to figure 4, an increase in cement production has been seen during the beginning of 2018, registering a total of 802.00 metric tons (MT), which meant a rise of $0.2 \%$ compared to the level obtained in January $2017^{7}$.

With this productive increment in the cement industry, measures must be taken to contribute positively to the care of the environment. However, the production of some toxic solid particles constitutes a problem in agriculture, and discomfort in surrounding populations.

Granulometric analyses show that 25\% of the particles are between 1 and 10 microns that could be mobilized over vast distances. About 3\% of these particles are submicronic considered very harmful if they were in high concentrations at ground level.

The contamination also occurs at the air level due to the emission of combustion gases containing carbon monoxide and carbon dioxide in addition to the presence of water pollutants that are produced by the spilling of feed material from the oven, producing $\mathrm{pH}$ changes. The presence of suspended and dissolved solids, the presence of leachate in the areas where the contents are stored, is also a potent water pollutant.

Taking into account the process of gradual deterioration of our planet, alternatives that allow balancing this process produced mainly by the hand of man should be considered so, in this work we propose as an alternative, familiarize the scientific community in the application of biotechnological tools in the Cement industry that includes the use of microorganisms and their potential characteristics.

\section{Updating biotechnologies applied to construction materials. progress and challenges}

After three centuries of industrialization, human beings see themselves in the overwhelming need to seek potential in natural systems. This potential in the area of construction currently translates into the creation of new bio-inspired materials, which mix biological and engineering processes within a research area called biotechnology.

Martin-Manzanares ${ }^{8}$ proposes three possible directions of application of biotechnologies to the construction industry: 1- work with $100 \%$ organic material with thermal insulation functionality and structural qualities, 2- the use of micro luminescent micro-organisms for the design of devices with the ability to emit light without electricity consumption, and 3- cementation of granular structures mediating the use of environmentally friendly bacterial populations, without toxicity or corrosion.

Concrete is a material used in construction that dates back to ancient Greece, with approximately 500 B.C., the elements used in its elaboration were modified by the Romans, who implemented in buildings such as the Colosseum and the Pantheon of Agrippa. Its reliability of use in construction, tension, and time generates deterioration in its structure and causes the appearance of cracks, which allow the filtration of rainwater until it reaches the steel reinforcements, which causes them to erode.

Development of materials and construction systems requires the study of microorganisms such as bacteria, fungi or algae, in the improvement of properties of conventional materials such as concrete; in the creation of new construction materials with similar characteristics to existing materials, with the advantage that their production processes are more sustainable; and in the incorporation of some of these microorganisms into new construction systems, which in addition to providing an aesthetic component, develop an energy task in the form of biomass.

Prototypes of use in cementing granular structures have been developed through the use of bacterial populations that deposit calcite, for the manufacture of bricks, soil stabilization and compaction, restoration of monuments and cracks in concrete, and construction of roads and other structures ${ }^{10}$.

Henk Jonkers ${ }^{11,12}$ developed a method that can be applied to concrete using microorganisms. After several experiments, this researcher chose calcium lactate as a substrate, supplied in biodegradable plastic capsules and added them in the wet mixture of bioproducts.

"We believe that our concrete will revolutionize the way it is currently built because we have been inspired by nature. Plants and animals can heal themselves so, we have achieved that concrete can imitate them," said Jonkers.

The human principle applied in Jonker 's theory is based on the human ability to regenerate bone tissue by mineralization.

In the same line and within this range of construction 
products, we have the Bio cement developed by the researchers of Delft Technical University (Holland) considered as a new type of cement with the capacity of self- regeneration in case of cracks or breaks ${ }^{10}$. The mixture of this cement contains bacteria that, on contact with water, can produce limestone that naturally could fill any fissure.

This self-repairable material contains granules with spores of bacteria and calcium lactate, a necessary nutrient that bacteria need to survive. The spores remain inactivated, pending an activation by contact with rainwater introduced by the cracks. Rainwater can activate the mechanism of calcite production that is the product of this reaction to fill the cement gaps.

Currently, researchers have confirmed the sealing of cracks up to $0.5 \mathrm{~mm}$ in laboratory phases. It is expected in the future to make it available in real conditions. The self-repairable cement could be on the market in two or three years.

For this process, he used the bacteria Bacillus pseudofirmus and Sporosarcina pasteurii, which can be found in lakes with high levels of salinity very close to volcanoes. The lifespan is a maximum of 200 years, allowing buildings to maintain their regenerative ability ${ }^{14}$. Bacteria also contribute to oxygen consumption preventing internal corrosion of reinforced concrete. On the other hand, bacteria do not pose a risk to humanity, since they are strict only to the alkaline conditions inside the material consisting of a $\mathrm{pH}$ higher than ten or extremely alkaline conditions.

"Self-healing concrete," consists of the same materials that conform conventional concrete (cement, water, fine and coarse aggregates, additives, etc.) added to the bacteria, which give it the quality of self-regenerating. When the concrete is exposed to cracks in the air, moisture, or water penetration, a chemical reaction is generated and as illustrated in figure 5 , the self-regeneration products and their chemical composition are observed.

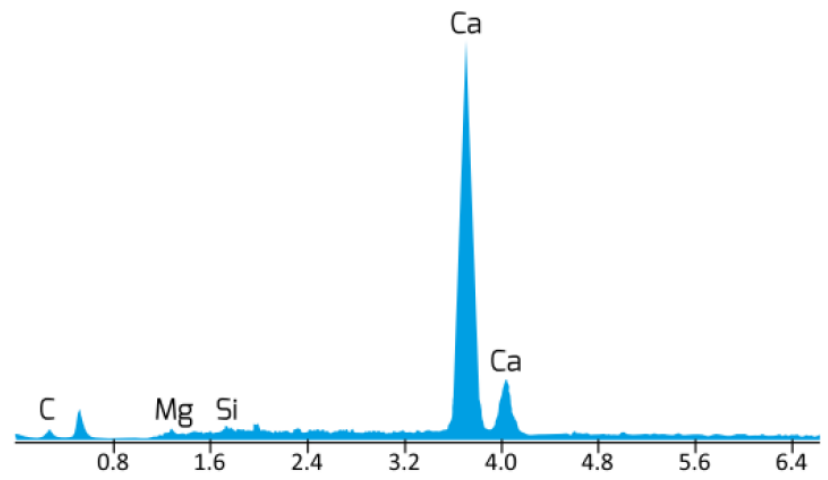

Figure 5. Chemical composition of self-regeneration products. The most substantial balance is $\mathrm{Ca}$, which is linked to the growth of calcites for the production of regenerative concrete.

\section{Microorganisms used in the concrete and bio cement production}

The world produced 4.3 billion metric tons of cement in 2014, and this production will continue to increase due to construction demand in the world ${ }^{15}$. Besides, cement production is a process that consumes energy and is harmful to the environment, since it contributes approximately $7 \%$ of the world's anthropogenic emissions of $\mathrm{CO}_{2}^{16}$.

Despite all the strength and durability, concrete has problems; one of them is the stress of transporting loads that gradually creates microscopic fissures in the material, which allows the entry of water, salts, and sometimes ice ${ }^{15}$.

However, natural processes, including earthquakes or weathering or subsidence of the earth and human activities, also perform sufficient functions to degrade or reduce the durability of concrete structures ${ }^{17}$.

The formation of ammonia is produced by the hydrolysis of urea when it meets moist air.

$$
\mathrm{CO}\left(\mathrm{NH}_{2}\right)_{2}+\mathrm{H}_{2} \mathrm{O} \leftrightarrow \mathrm{COOH}+2 \mathrm{NH}_{3}
$$

The carbonate of the concrete hydrolyzes and originates two products, ammonia, and carbonic acid.

$$
\mathrm{NH}_{2} \mathrm{COOH}+\mathrm{H}_{2} \mathrm{O} \leftrightarrow \mathrm{NH}_{3}+\mathrm{H}_{2} \mathrm{CO}_{3}
$$

From the products, there are two reactions from which bicarbonate, ammonium, and hydroxide ions originate, due to an increase in $\mathrm{pH}$.

$$
\begin{gathered}
\mathrm{HCO}_{3} \leftrightarrow \mathrm{HCO}_{3}^{-}+\mathrm{OH}^{-} \\
2 \mathrm{NH}_{3}+\mathrm{H}_{2} \mathrm{O} \leftrightarrow 2 \mathrm{NH}_{(14)}+2 \mathrm{OH}^{-}
\end{gathered}
$$

By increasing the $\mathrm{pH}$, the bicarbonate balance shifts to form carbonate ions.

$$
2 \mathrm{OH}^{-}+\mathrm{HCO}_{3}^{-}+\mathrm{H}^{+}+2 \mathrm{NH}_{4}^{+} \leftrightarrow \mathrm{CO}_{3}^{2-}+2 \mathrm{NH}_{4}^{+}+2 \mathrm{H}_{2} \mathrm{O}
$$

Through two reactions carried out by the bacteria, the carbonate ion precipitates giving rise to the product known as limestone.

$$
\begin{gathered}
\text { Cell }+\mathrm{Ca}^{2+} \leftrightarrow \text { Cell }-\mathrm{Ca}^{2+} \\
\text { Cell }+\mathrm{Ca}^{2+}+\mathrm{CO}_{3}^{2-} \leftrightarrow \text { Cell }-\mathrm{CaCO}_{3}
\end{gathered}
$$

Bacteria then are the main component that carries out the reactions that allow the material to repair the cracks to be generated, increasing their lifetime. 
To help reduce those maintenance costs and make buildings and bridges safer, researchers are now giving concrete the power to heal themselves.

Jonkers and Schlangen ${ }^{11}$ have led one of the first concrete jobs, where they take advantage of microorganisms to allow the concrete to heal itself; they mix clay granules containing calcium lactate and spores of limestone producing bacteria in the concrete (they use species of alkali-tolerant bacteria such as Bacillus pseudofirmus, which can survive the high $\mathrm{pH}$ of the concrete).

These bacterial spores can remain dormant for decades so that when the spores crack with the concrete, the moisture in the air causes the spores to germinate, the bacteria then feed on calcium lactate in the presence of moisture and oxygen to form Limestone, sealing the cracks.

This cure occurs in just three weeks, and bacteria can seal gaps up to $0.8 \mathrm{~mm}$ wide ${ }^{11}$. Another example of self-healing of concrete from bacteria is that presented by De Belie, where it packages bacterial spores in a melanin formaldehyde shell, generating a concrete that can cure small cracks up to $1 \mathrm{~mm}$ wide in four weeks.

Likewise, the same author mentions that a bacterial limestone producing strain was recently identified that does not require oxygen but uses nitrates, which would be added to the concrete so that microorganisms could potentially do their healing work in the structures of concrete where there is little access to air ${ }^{18}$.

There are other methods in which bacteria help in the production of concrete and bio cement. The most studied positive effect is the precipitation of microbe induced $\mathrm{CaCO}_{3}$ (MICP). The MICP in civil engineering has been considered mainly for its application in the fields of protection of natural stone surfaces, concrete crack remediation and soil improvement. Also, the development of the force by mixing bacteria in the concrete has been investigated ${ }^{18}$.

The initial application of bacterial calcium carbonate precipitation in civil engineering is for the consolidation of the surface and the protection of construction materials, specifically, historical stones and cement-based materials; the researchers started from the isolation of carbonogenic strains, then the bacteria were isolated mainly from environments that produce carbonates.

The most commonly used metabolic pathway is the bacterial ureolytic hydrolysis of B. pasteurii over urea. When the research was carried out on a laboratory scale, the methodology applied was immersion, in which the samples were immersed in bacterial cultures and deposition media during specific periods.

The immersion time varied from 3 to 30 days, depending on the bacterial activity. The bio- $\mathrm{CaCO}_{3}$ layer formed not only decreased water permeability, but both had strong cohesion within the layer and adhesion with the original matrix based on puncture resistance and ultrasonic measurement tests. This is due to the epitaxial growth of new crystals in the preexisting crystals and due to the incorporation of organic bacteria molecules ${ }^{19}$.

On the other hand, the cement industry has constantly been looking for procedures that effectively reduce the high energy requirements and environmental costs of cement manufacturing ${ }^{20}$.

The answer depends largely on the fact that the bio concrete that is based on the MICP process consists of three materials: alkalophilic microorganisms, substrate solution and calcium ion solution. It has been shown that the MICPbased bio concrete increases the durability of construction materials, the consolidation of sand columns and the repair of monuments and limestone concrete; besides, it can improve the strength and durability of structures, which are considered requirements for concrete or any other construction material ${ }^{16,21}$.

Bacteria are not the only microorganisms that can precipitate calcium carbonate; within this group are also algae and microalgae. Seaweeds are nature-friendly organisms and are used in the area of civil engineering to control the chemical reaction of cement, also, avoid voids and decrease the permeability of concrete ${ }^{22}$.

Microalgae are a promising means to be used in biocementation, due to their photosynthetic metabolism, algae species such as spirulina, Arthrospira plantensis (Cyanophyta), Chlorella vulgaris (Chlorophyta), Dunaliella salina, Haematococcus pluvialis, Muriellopsis sp., Porphyridium Cruentum (Rhodophyta) are autotrophic microorganisms that live through the photosynthetic process.

It was shown that through an experiment that was based on nine green algae, one diatom and three cyanobacteria precipitated $\mathrm{CaCO}_{3}$ in batch culture, where they were grown light in a hard water medium containing $68 \mathrm{mg} / \mathrm{L}$ of soluble calcium ${ }^{23}$.

Several types of microalgae also use the urea hydrolysis mechanism to meet the needs of nitrogen, for example, Chorella $s p$ uses urea as a source of nitrogen; Urea is hydrolyzed by urease or by the enzyme urea amidoliase to produce ammonia and bicarbonate, the activity of the urease enzyme can also induce precipitation of calcium carbonate ${ }^{24}$. There are some advantages of using microalgae as a means to produce biocement such as: availability as raw material, easy to grow, can reduce the $\mathrm{CO}_{2}$ emission that occurs in conventional cement production ${ }^{22}$.

On the other hand, its manufacture in the baking oven, requiring $50-85 \%$ less energy for its production, which represents $85 \%$ less $\mathrm{CO}_{2}$ released into the atmosphere, which is mainly used as ecological pavement due to its permeable properties $^{25}$.

\section{Comparison between bioconcrete and traditional concrete}

Mechanical properties and their effects. Concrete based on flexible engineering exhibits more ductile behavior, while ordinary concrete is fragile (Figure $6,7,8$ ). Inflexibility measurement tests, the results were 5 times higher than conventional concrete.

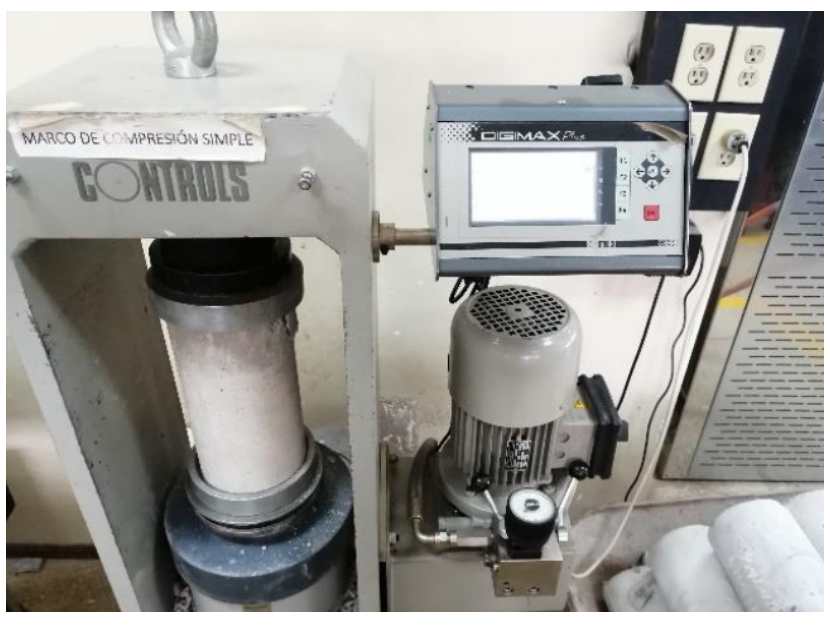

Figure 6. Tensile testing of concrete, bending deformation ${ }^{13}$. 


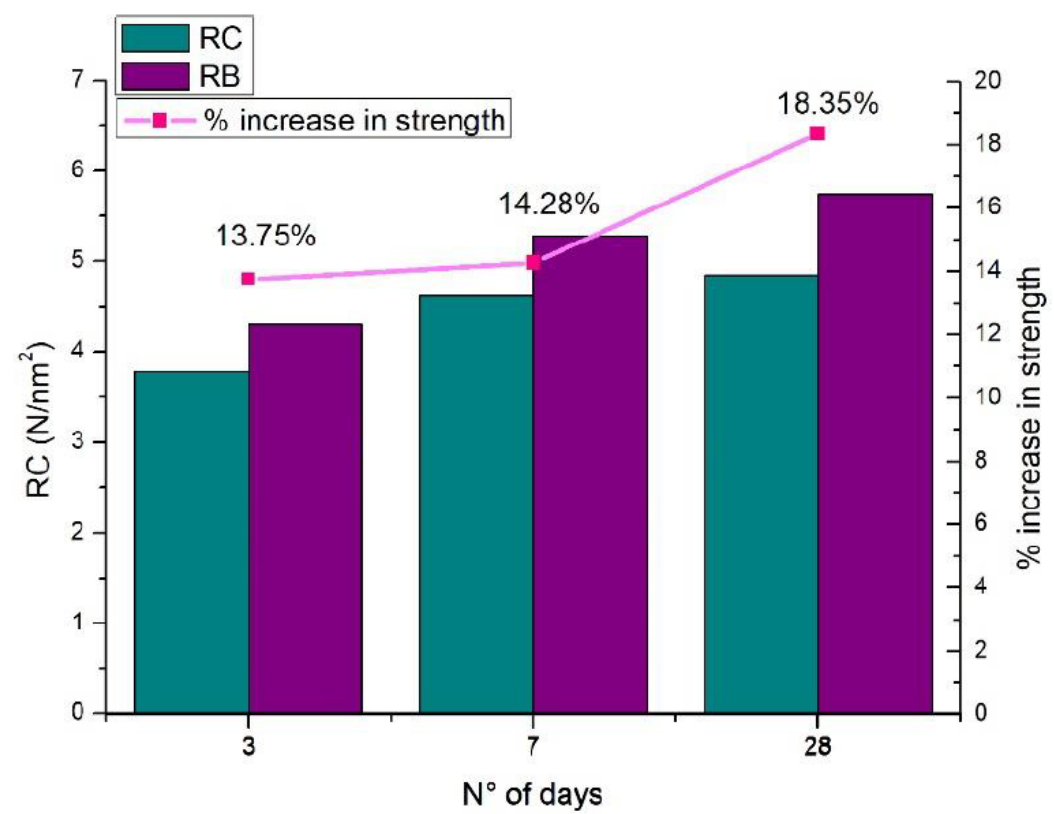

Figure 7. Comparison of the tensile strength values by splitting.

RC: Tensile strength of conventional concrete cylinders. RB: Tensile strength of B. sphaericus concrete cubes ${ }^{13}$.

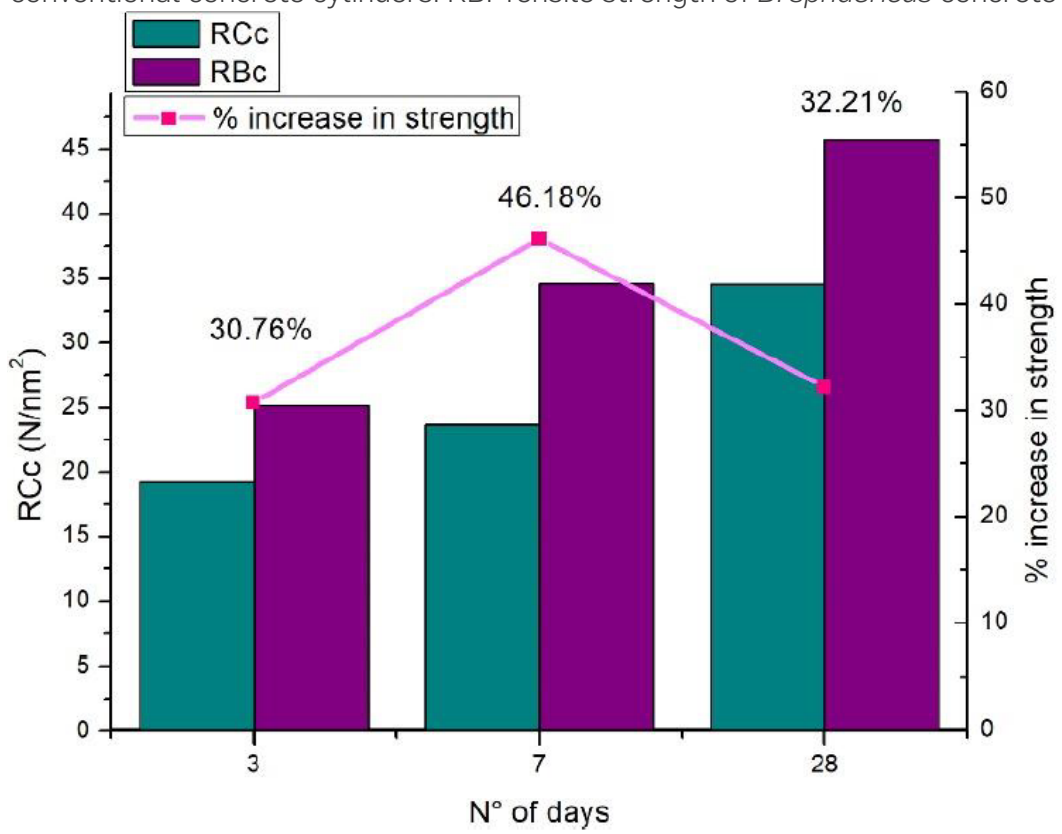

Figure 8. RC: Compressive strength (c) of conventional concrete cylinders. RB: Compressive strength (c) of B. sphaericus concrete cubes ${ }^{13}$.

\section{The durability of concrete, the effects.}

The expense in the repair of the cracks represents a considerable investment reason why to count on this technology avoids losses and inconveniences in the residents of the properties. Although the cost of this bio concrete is 3 times higher than traditional concrete, it is compensated by evading repair costs.

It grants permeability to concrete, has better properties in a hardened state compared to the traditional one that restricts corrosion in marine structures or basements.

\section{Fnvironmental advantages of construction biomaterial production}

According to the European Commissionn, the Paris agreement mentions that the cement sector is responsible for around $5 \%$ of carbon dioxide $\left(\mathrm{CO}_{2}\right)$ emissions, which is the main greenhouse gas and climate change producing gas.
Being concrete, one of the most widely used materials in the world in the construction industry employs 1.6 billion tons of cement, and each ton of cement emits 1 ton of $\mathrm{CO}_{2}$ into the atmosphere in its manufacture.

Besides that, during the construction process, heavy machinery is used that generates the highest amount of $\mathrm{CO}_{2}$ emissions. The transport of the materials to the site constitutes $6-8 \%$ of the total greenhouse gas emissions for a project.

On the other hand, the commercial and residential construction sector represents $39 \%$ of the $\mathrm{CO}_{2}$ emitted into the atmosphere, generating $30 \%$ of solid waste and $20 \%$ of water pollution. Based on the previous data, it can be concluded that half of the $\mathrm{CO}_{2}$ expelled into the atmosphere is related to the construction of buildings throughout all its phases: construction, use, and subsequent demolition. Therefore, the construction sector and its $\mathrm{CO}_{2}$ emission as a threat of climate change must be considered. 
Therefore, to reduce the environmental impact on the construction sector, it is essential to use materials that do not require the use of fossil fuels and cause high carbon emissions.

Among the bioconstruction materials that reduce $\mathrm{CO}_{2}$ emissions to the environment are:

Ecological calstar paver: this paper is made of at least $40 \%$ recycled materials, has the advantage of not needing high energy consumption during $\mathrm{CO}_{2}$ absorbing flooring, known as GeoSilex, is manufactured with waste from acetylene production, and incorporated into pavements and facades, it makes these surfaces acquire $\mathrm{CO}_{2}$ absorption capacity, it is marketed as additive paste for concrete, adding to these in a proportion of $3-10 \%$ of the weight of the concrete. It should be noted that it is a $100 \%$ product made of recycled material, and its carbon footprint during its manufacture is fully amortized, and that once its useful life is finished, it can then be recycled for the production of other materials, which represents a decrease significant in the release of $\mathrm{CO}_{2}$ to the environment ${ }^{27}$.

Green cement based on geopolymers, the main advantage in the production of this type of cement is the reduction of $\mathrm{CO}_{2}$ emissions during its production process since the processing of common cement uses fuels to heat limestone to a temperature of $1450^{\circ} \mathrm{C}$ to obtain lime, and by decarbonation of limestone, geopolymer-based cement does not use calcium carbonate in its preparation and can be manufactured at half the temperature $\left(750^{\circ} \mathrm{C}\right)$ and by-products of the manufacturing process they can be incorporated back into the production of this cement, which reduces up to $80 \%$ the environmental emissions involved in its development and with a production cost $50 \%$ lower than that of common cement.

\section{Conclusions}

Construction biomaterials are one of these novels, friendly and sustainable alternatives. Recent studies have shown that $\mathrm{CO}_{2}$ emission used in the construction industry represents approximately half of the $\mathrm{CO}_{2}$ emitted to the atmosphere so, this industry represents one of the main problems in the greenhouse effect and climate change, and therefore, it is necessary to look for alternatives to conventional methods of manufacturing building materials.

Bioconstruction materials such as ecological pavers, pavements to absorb $\mathrm{CO}_{2}$ and green cement based on geopolymers represent a desirable alternative to replace conventional materials in the construction induction since these reduce $\mathrm{CO}_{2}$ emissions to the atmosphere in an $80 \%$ in its manufacturing process compared to conventional methods, and in many cases, they represent a $50 \%$ decrease in its production costs.

\section{Bibliographic references}

1. Stabnikov, V. \& Ivanov, V. Biotechnological production of biopolymers and admixtures for eco-efficient construction materials. in Biopolymers and Biotech Admixtures for Eco-Efficient Construction Materials (2016). doi:10.1016/B978-0-08-100214-8.00003-8

2. Ivanov, V. \& Christopher, L. Biorefinery-derived bioplastics as promising low-embodied energy building materials. in Nano and Biotech Based Materials for Energy Building Efficiency (2016). doi:10.1007/978-3-319-27505-5_13

3. Ivanov, V. \& Stabnikov, V. Construction Biotechnological Plastics. in (2017). doi:10.1007/978-981-10-1445-1_4

4. Castillo, N. A., Valdez, A. L., Fariña, J. I., Masuelli, M. \& Eds, D. R. CHAPTER 2 Biopolymers of Microbial Origin. in Advances in Physicochemical Properties of Biopolymers (2017).
5. Padinjakkara, A. Biopolymers and Biomaterials. Biopolymers and Biomaterials (Apple Academic Press, 2018). doi:10.1201/9781315161983

6. Anonymous. Cemento. Oligopolio? Ekos 23-25 (2012).

7. Anonymous. Mercado del cemento empieza el 2018 con el pie derecho, ¿qué resultados obtuvo? Gestión 1 (2018).

8. Martín Manzanares, C. Construcción viva: sinergia entre materiales y microorganismos. (Universidad Politécnica de Madrid (UPM), 2017).

9. Anonymous. Concreto vivo o bioconcreto. Bioconcreto 1 (2015). Available at: http://concretovivomc.blogdiario.com/tags/bioconcreto.

10. Anonymous. Bio cemento capaz de auto repararse. Blog Eraikal 1 (2012). Available at: http://eraikal.blog.euskadi.eus/ blog/2012/11/05/bio-cemento-capaz-de-auto-repararse/.

11. Jonkers, H. M. \& Schlangen, E. Development of a bacteria-based self healing concrete. in Proceedings of the International FIB Symposium 2008 - Tailor Made Concrete Structures: New Solutions for our Society (2008). doi:10.1201/9781439828410.ch72

12. Jonkers, H. M., Mors, R. M., Sierra-Beltran, M. G. \& Wiktor, V. Biotech solutions for concrete repair with enhanced durability. in Biopolymers and Biotech Admixtures for Eco-Efficient Construction Materials (2016). doi:10.1016/B978-0-08-100214-8.00012-9

13. Ponce, C. et al. Los beneficios del uso de bacterias en el concreto autorregenerante. Civilizate (2015).

14. Anonymous. BioConcreto: un material que tiene la capacidad de autorepararse. EL DIA 1 (2015).

15. Patel, P. Helping concrete heal itself. ACS Cent. Sci. (2015). doi:10.1021/acscentsci.5b00376

16. Achal, V. Production of bacteria for structural concrete. in Biotechnologies and Biomimetics for Civil Engineering (2015). doi:10.1007/978-3-319-09287-4_14

17. Reddy, M. S., Achal, V. \& Mukherjee, A. Microbial concrete, a wonder metabolic product that remediates the defects in building structures. in Microorganisms in Environmental Management: Microbes and Environment (2012). doi:10.1007/978-94-0072229-3_24

18. De Belie, N. Application of bacteria in concrete: a critical evaluation of the current status. RILEM Tech. Lett. (2016). doi:10.21809/ rilemtechlett.2016.14

19. Wang, J. Y., Snoeck, D., Van Vlierberghe, S., Verstraete, W. \& De Belie, N. Application of hydrogel encapsulated carbonate precipitating bacteria for approaching a realistic self-healing in concrete. Constr. Build. Mater. (2014). doi:10.1016/j.conbuildmat.2014.06.018

20. Rong, H., Qian, C. X. \& Li, L. Z. Study on microstructure and properties of sandstone cemented by microbe cement. Constr. Build. Mater. (2012). doi:10.1016/j.conbuildmat.2012.06.063

21. Achal, V., Mukherjee, A. \& Reddy, M. S. Microbial concrete: A way to enhance durability of building structures. in 2nd International Conference on Sustainable Construction Materials and Technologies (2010). doi:10.1061/(ASCE)MT.1943-5533.0000159

22. Ariyanti, D. Feasibility of Using Microalgae for Biocement Production through Biocementation. J. Bioprocess. Biotech. (2012). doi:10.4172/2155-9821.1000111

23. Ramasubramani, R., Praveen, R. \& Sathyanarayanan, K. S. Study on the strength properties of marine algae concrete. Rasayan J. Chem. (2016).

24.Perez-Garcia, O., Escalante, F. M. E., de-Bashan, L. E. \& Bashan, Y. Heterotrophic cultures of microalgae: Metabolism and potential products. Water Research (2011). doi:10.1016/j. watres.2010.08.037

25. Anonymous. Geopolimeros. ARQHYS 1 (2012).

26. Comisión Europea. Acuerdo de París | Acción por el Clima. Polices, information and services. Acciones de la UE (2015).

27. García, P., Barrionuevo, R., Villegas, C., Moromi, I. \& Carvajal, G. consolidación de material de construcción por proceso de biomineralización. Rev. Tec. (2018). doi:10.21754/tecnia.v28i1.183

Received: 20 December 2019

Accepted: 22 January 2020 